\title{
Spermatogenesis and plasma testosterone levels under field conditions, in males of the common toad (Rhinella arenarum Hensel, 1867), from the Monte Desert, Argentina
}

\author{
Lorena Quiroga ${ }^{1,4, *}$, Eduardo Sanabria ${ }^{1,4}$, \\ Graciela Jahn ${ }^{2,4}$ \& Miguel Fornés ${ }^{3,4}$
}

\author{
${ }^{1}$ Instituto de Ciencias Básicas (ICB), Facultad de Filosofía Humanidades y Artes, Universidad \\ Nacional de San Juan, San Juan, Argentina, CP 5400. \\ ${ }^{2}$ Laboratorio de Reproducción y Lactancia (LARLAC), Instituto de Medicina y Biología Experimental \\ de Cuyo (IMBECU), Mendoza, Argentina, CC855, CP 5500. \\ ${ }^{3}$ Laboratorio de Investigaciones Andrológicas de Mendoza (LIAM), Instituto de Histología y \\ Embriología de Mendoza (IHEM), Facultad de Ciencias Médicas, Universidad Nacional de Cuyo, \\ Mendoza, Argentina, CP 5500. \\ ${ }^{4}$ Consejo Nacional de Investigaciones Científicas y Técnicas (CONICET), Avenida Rivadavia 1917, \\ Ciudad Autónoma de Buenos Aires, Argentina CP C1083ACA. \\ *Corresponding author: quirogalb@gmail.com
}

\begin{abstract}
The reproductive function in anurans depends on interactions between the hypothalamus, adenohypophysis and gonads, which are mediated by an endocrine circuit. We studied the relationship between reproductive and histological parameters, variation in spermatogenic activity, and plasma testosterone concentration cycle for a population of Rhinella arenarum under field conditions in the Monte Desert of Argentina. We captured 28 adult male R. arenarum from December 2009 to November 2010 , and define two seasons (wet and dry seasons). We performed histological analyses of the testes and used radioimmunoassay to determine plasma testosterone concentrations. Our results showed no difference in testicular volume between the wet and dry seasons, but found that changes in the fat body mass were higher in the dry season. The spematogenic cycle was characterized by the prominent presence of spermatogonia at the end of the dry season and the wet season. We also observed a higher percentage of primary spermatocytes in the wet season. In addition, we found that $R$. arenarum showed a continuous spermatogenic cycle, and spermatogenesis produced a high percentage of sperm bundles in the dry season, concordant with high levels of testosterone. Testosterone levels were highest during the dry season $(33.89 \pm 7.85 \mathrm{ng} / \mathrm{ml})$. Our data indicate that plasma testosterone showed a "dissociation" from reproductive activity such that the two parameters are asynchronous during the reproductive season. The characteristics of the reproductive cycle of $R$. arenarum allow this species the plasticity to colonize different environments, from tropical regions to deserts.
\end{abstract}

KEYWORDS. Argentina, Rhinella arenarum, reproduction, spermatogenesis, testosterone.

Quiroga L., Sanabria E., Jahn G. \& Fornés M. (2018). Spermatogenesis and plasma testosterone levels under field conditions, in males of the common toad (Rhinella arenarum Hensel, 1867), from the Monte Desert, Argentina. Belgian Journal of Zoology 148 (1): 105-118. https://doi.org/10.26496/bjz.2018.20 


\section{Introduction}

Anurans exhibit some of the most diverse reproductive strategies and adaptations known among vertebrates including, internal and external fertilization, oviparity and viviparity, direct and indirect development, and many forms of parental care such as the eggs or young are carried on or embedded in their backs, in pouches, and even in vocal sacs and stomachs (DUELLMAN \& TRUEB 1994; STEBBINS \& COHEN 1997; WELLS 2007; CRUMP 2015). The reproductive activity is often synchronized and adapted to environmental conditions such as temperature, photoperiod, humidity and food availability (FERNÁNDEZ \& RAMOS 2003). Due to the diverse environments in which anurans live, they have developed a diverse range of reproductive strategies. These reproductive strategies are optimal combinations of morphological, physiological, behavioral, and life history traits that maximize reproductive success under particular environmental and evolutionary constraints (PEROTTI 1997). Adaptation to varied environments requires some adjustments of the reproductive cycle to produce offspring during the period of the year in which the majority of offspring have the greatest chance of survival (CALLARD et al. 1978; DE SOUZA SANTOS 2006). Many organisms are able to perceive changes in the environment and modify their physiology accordingly (DE Souza SANTOS \& De Oliveira 2008). In the desert, one of the main factors that triggers reproductive behavior is rain (DUELLMAN \& TRUEB 1994).

Spermatogenesis is a highly conserved process in all vertebrate species (JøRGENSEN 1992). Spermatogenic conditions vary with environmental circumstances: in relatively constant environments, such as the tropics or in the laboratory, spermatogenesis may be continuous (RASTOGI 1976; SASSO-CERRI et al. 2004). In contrast, in fluctuating environments (e.g., desert systems), spermatogenesis is expected to be quiescent during the non-reproductive, winter months (MONTERO \& PISANÓ 1990, 1992).

In anurans, stored lipids may be used for metabolic maintenance during aestivation and/or for gonadal activity in reproduction (LONG 1987). Abdominal fat bodies are important for physiological regulation and are thus likely to vary seasonally. Fat bodies are located in the anterior margin of the testes and function as nutritional reserves due to being rich in cholesterol and triglycerides (DE SouZA SANTOS \& DE OliVEIRA 2008). Both fat bodies and the testes may differ in size throughout the reproductive cycle (HUANG et al. 1997; HUANG \& YU 2005); the fat body size is reduced or disappears during the breeding period of anurans because it is used as an energetic resource for the first egg clutches (JøRGENSEN 1992). Anurans from xeric regions have fat bodies that reach their minimum size at emergence from dormancy and their maximum size when they enter the next period of dormancy (LONG 1989; SEYMOUR 1973). Therefore, toad mass and body size, testicular volume, and mass of the fat bodies are important life history parameters (PEROTTI 1997).

Reproductive function in anurans is dependent on interactions between the hypothalamus, adenohypophysis, and gonads, which are mediated by an endocrine circuit (CHIEFFI et al. 1980). Stimuli such as environmental signals (abiotic factors as well as number of light hours, temperature, humidity or a combinations of factors), biological signals, and stimuli regarding the social environment are transmitted to the central nervous system. These stimulate the gonads to produce gametes (oocyte or sperm) and release sex steroids such as estrogen and testosterone (LiCHT et al. 1983). In anuran males testosterone increases reproductive success by promoting sexual behavior, secondary sexual characters, and sperm production (HAU 2007). Testosterone levels vary, however, depending on the reproductive strategy in amphibians (dissociated and associated strategies) (CREWs \& MOORE 1986; SHALAN et al. 2004): the 'dissociated' reproductive strategy is characterized by high levels of plasma testosterone in association with inactive spermatogenesis during aestivation. Therefore, during breeding, testosterone levels decrease and are thus disassociated with the reproductive period (DELGADO et al. 1989). In the 'associated strategy', plasma testosterone levels fluctuate simultaneously with spermatogenic activity during the reproductive period (RASTOGI et al. 1986). Reproductive activity appears to be associated with high plasma levels of androgens in anuran species such as Lithobates catesbeianus (= Rana catesbeiana (Shaw, 1802)) (MENDONÇA et al. 1985), Agalychnis dacnicolor (= Pachymedusa 
dacnicolor (Cope, 1864)) (RASTOGI et al. 1986) and Hypsiboas faber (Wied-Neuwied, 1821) (DE AssIS et al. 2012). However, some species, such as Pelophylax ridibundus (= Rana esculenta (Linnaeus, 1758)) (RASTOGi et al. 1976), Taricha granulosa (Skilton, 1849) (SPECKER \& MOORE 1980) and Bufo japonicus (Temminck \& Schlegel, 1838) (IтоH et al. 1990), express low androgen levels in summer, when spermatogenesis is at a maximum.

Animals that live in arid and semi-arid environments must face low rainfall, low humidity and high environmental temperatures, which require adaptive changes in several key physiological and reproductive processes (WHITFORD 2002; TIELEMAN et al. 2002; BROWN et al. 2011; KORDONOWY et al. 2017). In contrast to amphibians from temperate and tropical zones in North and Central America, which have received considerable attention, desert-adapted species from South America are relatively understudied (ARZABE 1999; CANOSA et al. 2003; DENARI \& CEBAllos 2005; MADELAIRE \& GOMEZ 2016; MADELAIRE et al. 2017). The common toad Rhinella arenarum, inhabits arid and subarid environments of western and central Argentina. This species is widely distributed in Argentina from northern Jujuy Province to the Río Chubut in Patagonia. Despite it being one of the most common anurans in this region, most aspects of the ecology of this toad are not well known (CEI 1980; GALLARDO 1987).

For $R$. arenarum, androgens do not appear to be associated with reproductive activity because testosterone levels decrease significantly during the breeding season in males (CANOSA \& CEBALLOS 2002; DenARI \& CEBALlos 2005). MedinA et al. (2004) analyzed the seasonal rhythms of sex steroids of females of $R$. arenarum in the Tucumán province, Argentina and found high levels of testosterone and dihydrotestosterone (DHT) during the pre-ovulatory period when oogenesis was advanced (JulyAugust).

Our aim was to study the reproductive cycle of males of $R$. arenarum from the Monte Desert under field conditions, with emphasis on, a) variation of spermatogenic activity: the relationship between reproductive and histological parameters, and b) plasma testosterone concentration cycles. We hypothesized that $R$. arenarum would exhibit continuous spermatogenesis, consistent with the typical pattern of desert anuran species that occur in areas characterized by unpredictability in climate. Alternatively, gonadal maturation could show synchrony with circulating levels of testosterone.

\section{Materials and methods}

La Quebrada de Las Flores is located $55 \mathrm{~km}$ east of the city of San Juan in the Caucete Department $\left(31^{\circ} 31^{\prime} \mathrm{S}, 67^{\circ} 51^{\prime} \mathrm{W} ; 800 \mathrm{~m}\right)$, Argentina. The dominant vegetation in the area includes Deuterocohnia longipetala (chaguar), Larrea sp. (jarillas), Prosopis sp. (algarrobos), and Bacharis salicifolia (chilca dulce). This region is part of the Monte Desert characterized by an arid climate, with precipitation concentrated in summer and with regimes of high average temperatures and large thermal amplitudes (CABRERA 1976). $R$. arenarum reproduces in spring, when water levels increase due to ice melt. The creeks have small flows and are subject to great evaporation. Thus, creeks experience both daily and seasonal variation in water levels and form salt layers at the margins. During the summer period (December - February), rainfall produces considerable (increasing) runoff, which removes a large amount of material with speed. This type of environment ('slopes') is scarce in the mountainous area and represents the only available water resource for the regional fauna.

We visited the study area during seven month and captured 28 adult male of $R$. arenarum between December 2009 and November 2010. We collected individuals randomly using visual encounter surveys during the reproductive season (HEYER et al. 2001). During aestivation (austral winter: May to July), we used shovels and crowbars to lift rocks and collect toads. All specimens used in the experiments were acquired according to legal regulations concerning the protection of wild species.

All toads were captured by hand, then weighed (corporal mass $=\mathrm{CM}$ ) with a digital scale (Denver, USA up to $0.1 \mathrm{~g}$ precision) and measured (snout vent-length, SVL) with calipers. We anesthetized toads with 
an intraperitoneal dose of $1 \mathrm{ml}$ Xylocaine $2 \%$. Immediately after the anesthetic, a blood sample was taken via cardiac puncture using a $1 \mathrm{ml}$ heparinized syringe. We obtained $\sim 800 \mu \mathrm{l}$ of blood from each of 28 individuals, which was immediately centrifuged for $15 \mathrm{~min}$ at $3000 \mathrm{rpm}$ (Centrifuge Eppendorf Presvac-EPF-12 CFE-16, Argentina). The plasma was removed, stored in microcentrifuge tubes, and frozen at $-20^{\circ} \mathrm{C}$ until processing.

After blood extraction, males were euthanized by a lethal injection of anesthesia ( $2.5 \mathrm{ml}$ of $2 \%$ xylocaine and $2 \%$ lidocaine $\mathrm{HCl}$, Astra Zeneca Labs, Bs. As., Argentina) into their lymphatic sacs. We removed both testicles and measured the length and width of each right testis with a digital caliper (accuracy: $0.01 \mathrm{~mm}$; Essexs; China). We calculated the testicular volume (TV) using the spheroid formula (DUNHAM 1983). We also cut the testicles into small pieces and fixed them by immersion in a fixative solution (4\% glutaraldehyde (v/v), 2\% of freshly prepared paraformaldehyde (v/v) in saline phosphate buffer PBS). We extracted the fat bodies, which were weighed (FBM) on a digital scale (Denver; $0.001 \mathrm{~g}$, USA).

Histological analyses of the testes were performed on 28 males. Ten sections $(6 \mu \mathrm{m})$ of each right testis were stained using the hematoxylin and eosin method, examined with a light microscope (Ultraphot Zeiss, Germany), and photographed with a digital camera (MTI, Dage, USA). Photomicrograph analyses were performed using Image J (RASBAND 2008). The surface area of each seminiferous tubule was calculated using the formula for the surface of an ellipse $\left[\mathrm{Se}=\chi^{*} \mathrm{Mrt} * \mathrm{mrt}\right]$ where, $\mathrm{Mrt}=$ major radius of tubule, $\mathrm{mrt}=$ smaller radius tubule.

Spermatogenic activity was assessed qualitatively, and the order of spermatogenic stages were determined following DE OliveIRA et al. (2003): primary, and secondary spermatogonia (I SPG, II SPG), primary, and secondary spermatocytes (I SPC, II SPC), spermatids (SPT), sperm bundles (SB), and spermatozoa (S). We analyzed micrographs to determine the relative area of each spermatogenic stage present in each testis, relative to the total surface of a seminiferous tubule as $100 \%$ coverage.

We determined the plasma testosterone concentrations in 28 male toads by radioimmunoassay (RIA) using a [I-125]-Testosterone RIA Coat-A-Count Total Testosterone commercial kit (Siemens AG, Erlangen, Germany). To validate the testosterone RIA for $R$. arenarum plasma, we assayed all samples in parallel: (1) plasma with no treatment; (2) plasma acidified with addition of $10 \% \mathrm{v} / \mathrm{v}$ of $\mathrm{HCl} 0.1 \mathrm{~N}$ to dissociate steroids from circulating SHBG (sex hormone-binding globulin) or other circulating steroid binding proteins; and (3) plasma extracted twice with $10 \mathrm{v} / \mathrm{v}$ ethyl ether, evaporated, and dissolved in assay buffer. The best recovery was obtained using the ethyl ether procedure so we analysed all 28 samples using this method. Serial dilutions of some samples gave values that were parallel to the standard curve. The efficiency of the ethyl ether procedure was higher than $95 \%$ for the concentrations assayed, which were 2 and $50 \mathrm{ng} / \mathrm{ml}$ testosterone added to charcoal extracted plasma. For the RIA, $60 \mu \mathrm{l}$ aliquots of ethyl ether plasma were used, and the procedure was performed according to the manufacturer's instructions. Values were corrected for the 10\% dilution factor and expressed as ng/ $\mathrm{ml}$. Assay sensitivity was $0.2 \mathrm{ng} / \mathrm{ml}$ plasma. We evaluated all results with respect to two seasons: the wet season, characterized by the presence of heavy rains (November to March) with mean maximal temperature of $30.7^{\circ} \mathrm{C}$, minimum temperature of $19.6^{\circ} \mathrm{C}$, and a mean rainfall of $84 \mathrm{~mm}$; and the dry season which extends from April to October. The dry season is characterized by a mean maximal temperature of $20^{\circ} \mathrm{C}$, minimum temperature of $6^{\circ} \mathrm{C}$, and mean rainfall of $1.9 \mathrm{~mm}$ (CABRERA 1976).

Statistical Analyses: Normality and variance-homogeneity assumptions were tested using the Kolmogorov-Smirnov and Levene tests. When the assumptions were violated, a non-parametric Mann Whitney U-Test and median values were used. When values were normal and variances homogeneous, we used an ANCOVA with SVL as the covariate. The values of all variables are shown as means \pm SE. The relationships among variables were analyzed using non-parametric Spearman correlations. We implemented all analyses in the PAST statistical software version 9.4 (HAMMER et al. 2001) statistical packet. 


\section{Results}

Snout-vent length (SVL) of adult males of $R$. arenarum $(\mathrm{n}=28)$ ranged from 90.5 to $109.3 \mathrm{~mm}$ (mean = $101.5 \pm 0.92 \mathrm{~mm}$ ), Fat Body Mass (FBM) varied from 0.004 to $4.6 \mathrm{~g}($ mean $=1.4 \pm 0.2 \mathrm{~g})$, and Testicular Volume (TV) varied from 25.9 to $178 \mathrm{~mm}^{3}$ (mean $\left.=92.9 \pm 6.3 \mathrm{~mm}^{3}\right)$.

The TV did not differ between the months studied (ANOVA, $F_{(6.18)}=0.91, P>0.5$, Cov: SVL). There was no significant relationship between TV and SVL $(P>0.09)$, and FBM was correlated with TV (Spearman Correlation: $R=0.47, P>0.01, n=28$ ). Also, FBM was higher in the months of March and May (ANCOVA, $F_{(6.20)}=3.66, P<0.01$, Cov: SVL; Fig. 1 ).

FBM was negatively correlated with the II SPG (Spearman Correlation: $R=-0.39, P<0.03, n=28$ ). In contrast, we observed a positive correlation between SB and FBM (Spearman Correlation: $R=0.37$, $P<0.04, n=28)$.

The spematogenic cycle was characterized by the greater abundance of SPG (I SPG + II SPG) at the end of the dry season and wet season (Fig. 2). I SPC and II SPC cells were more abundant during the wet season (Fig. 4A). SPT were more abundant in September, and the sperm bundles were more abundant in May and July (dry season) before breeding (Fig. 4B). Finally, spermatozoal count was highest in the dry season (July; Fig. 2).

Overall, the plasma concentration of testosterone in males of $R$. arenarum varied throughout the study (ANOVA $F_{(6.21)}=3.05, P<0.02$; Fig. 3). It was lowest in the wet season (mean $=33.89 \pm 7.85 \mathrm{ng} / \mathrm{ml}$ $(n=16)$ and highest in the dry season (mean $=146.45 \pm 37.08 \mathrm{ng} / \mathrm{ml}\left(n=12\right.$; ANOVA: $F_{(1.26)}=11.50$, $P<0.002)$ ). The Fisher LSD post-hoc test validated differences in the concentration of plasma testosterone across the seven months of the study. We observed the largest difference between concentrations in May and in the months of December, February and March. Plasma testosterone was also higher in July compared to February and March, and higher in May compared to November and September (Fig. 3).

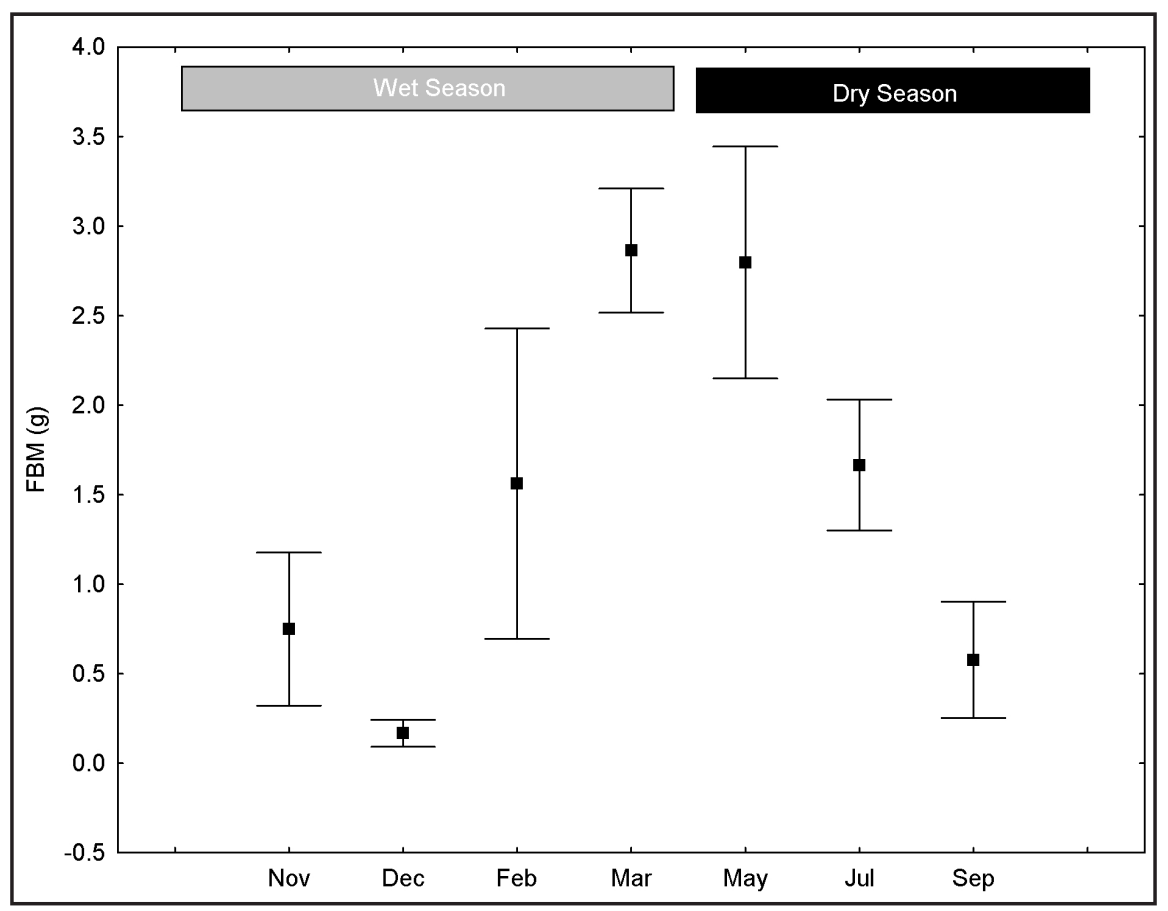

Figure 1 - Fat body mass (FBM) during the months of sampling in male Rhinella arenarum from Monte Desert. Means \pm standard errors are depicted. Black box $=$ dry season months; grey box $=$ wet season months. 


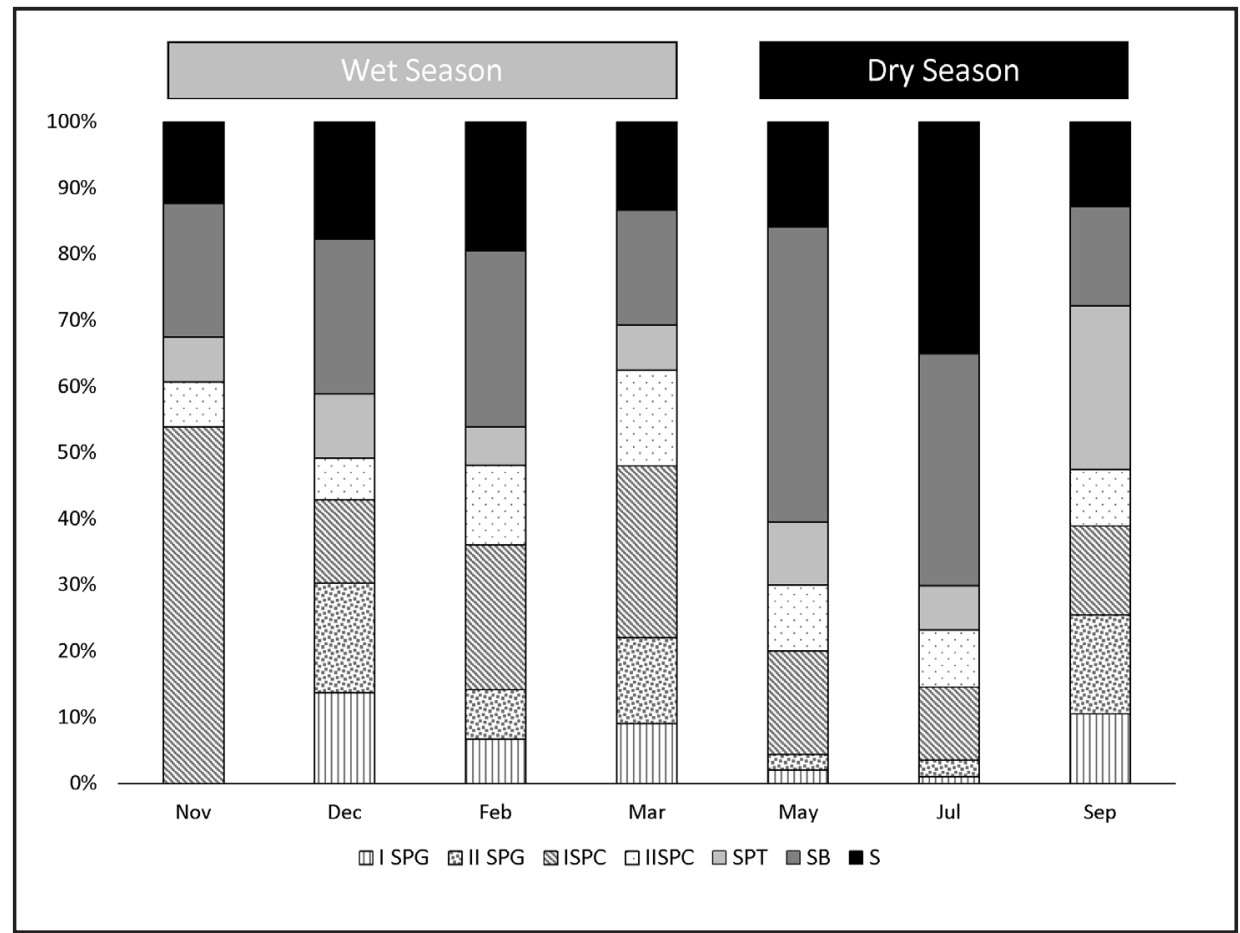

Figure 2 - Percentages of the different stages of spermatogenesis observed in each month of sampling in male Rhinella arenarum from Monte desert, Argentina. Abbreiations: ISPG = primary spermatogonia; II SPG $=$ secondary spermatogonia; I SPC $=$ primary spermatocytes; II SPC $=$ secondary spermatocytes; $\mathrm{SPT}=$ spermatids $; \mathrm{SB}=$ sperm bundles; $\mathrm{S}=$ spermatozoids. Black box $=$ dry season months; grey box $=$ wet season months.

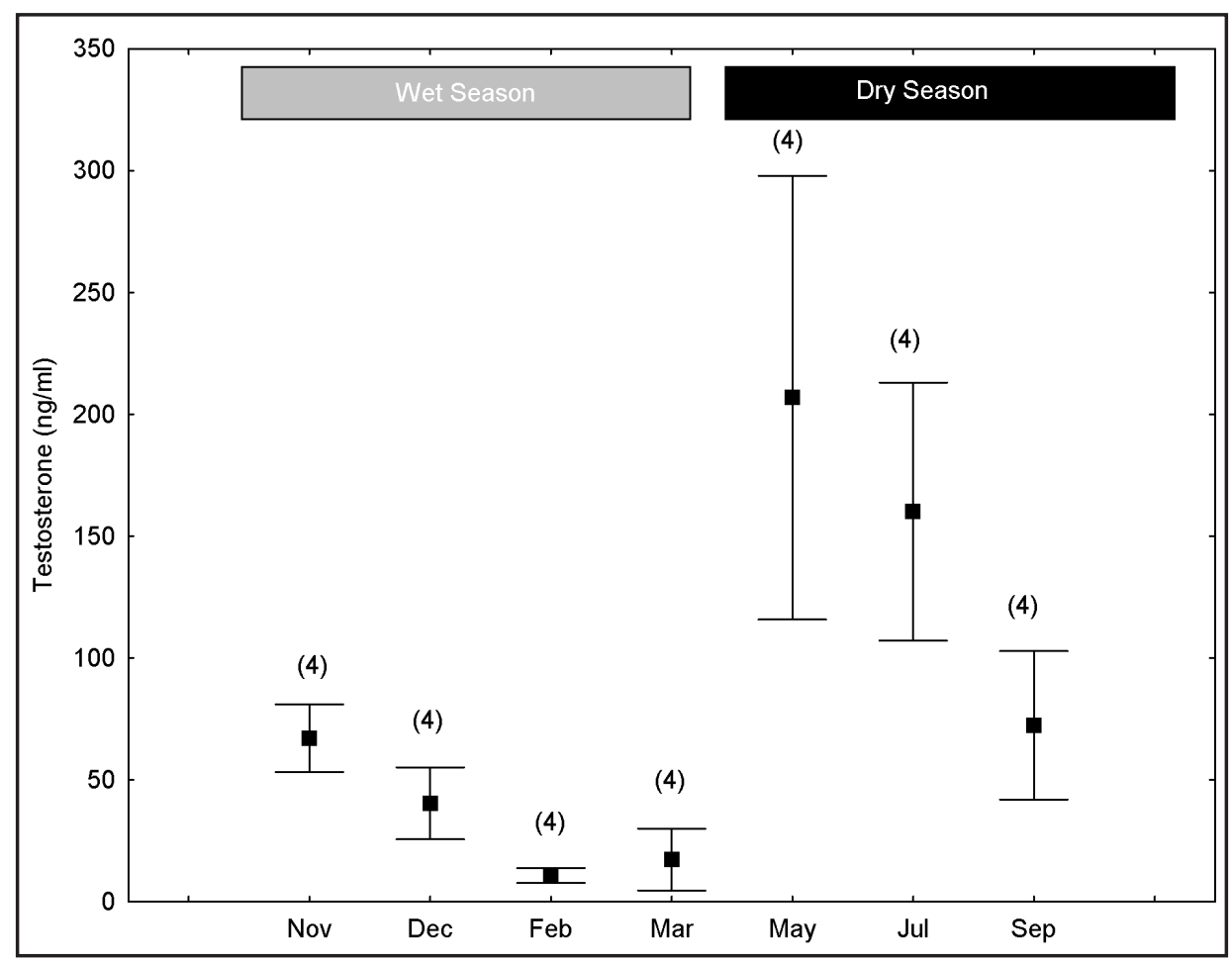

Figure 3 - Plasma testosterone concentrations in male Rhinella arenarum in the sampled months. Means \pm standard errors are depicted. Sample sizes in brackets. Black box $=$ dry season months; grey box $=$ wet season months. 
We did not observe a correlative relationship between testosterone levels and the following reproductive variables: TV $(P>0.50)$, FBM $(P>0.92)$, and body mass $(P>0.49)$, or SVL $(P>0.42)$. Further, we found no relationship between testosterone and the following variables: I SPG $(P>0.94)$, II SPG $(P>$ $0.94)$, II SPC $(P>0.25)$, SPT $(P>0.44)$, spermatozoa $(P>0.91)$, or surface area of seminiferous tubules $(P>0.90)$. However, testosterone levels did show a relationship with I SPC (Spearman, $R=-0.52, P<$ $0.01, n=19)$, and with SB (Spearman, $R=0.50, P<0.02, n=19$ ).
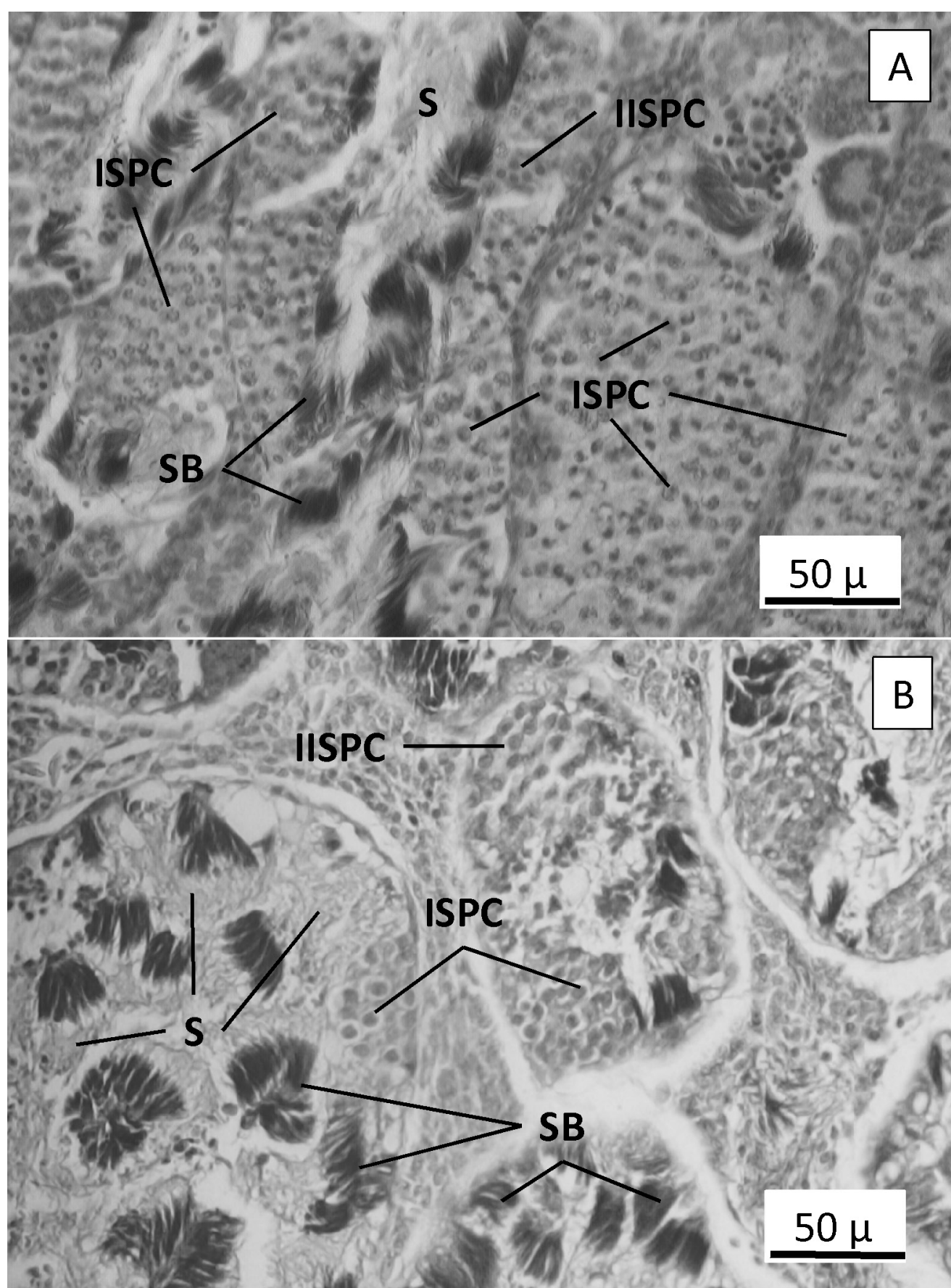

Figure 4 - Photomicrographs showing stages of spermatogenesis present in the seminiferous loculi of male Rhinella arenarum in (A) November and (B) May. Abbreviations: I SPC = primary spermatocytes; II $\mathrm{SPC}=$ secondary spermatocytes; $\mathrm{SB}=$ sperm bundles; $\mathrm{S}=$ spermatozoids. 


\section{Discussion}

Fat bodies are considered an important nutritional reserve for the gonads and body (CHIEFFI et al. 1980). We observed high fat body mass in $R$. arenarum at the end of the wet season and early dry season. Fat bodies enlarge following breeding (at the end of dry season), attributed to food consumption (QUIROGA et al. 2009). Thus, fat bodies serve as energy reserves for $R$. arenarum for estivation and for breeding the following year when males consume only a small amount of food (WOOLBRIGHT 1989). We observed that $R$. arenarum have empty stomachs during the breeding period (call activity) in the Monte desert (pers. obs.), indicating that this species probably uses fat bodies not only as a reserve for gonadal development (sperm production) but also as a reserve for activities that require high energy expenditure during the breeding season (CHIEFFI et al. 1980; TSIORA \& KYRIAKOPOUlOU-SKLAVOUNOU 2001; CARVALHO et al. 2010), such as calling behavior and territorial defense of breeding sites (NAVAS et al. 2008).

CHIEFFI et al. (1980) demonstrated that removing the fat body in $R$. esculenta resulted in atrophic changes in the testes and the inhibition of spermatogenesis, demonstrating the importance of the fat body in spermatogenesis. In many species of amphibians, spermatogenesis begins immediately after the breeding season (SASSO-CERRI et al. 2004) when primary spermatogonia begin to develop. Here, we found a negative correlation between fat body mass and secondary spermatogonia. Therefore, this energy source would likely be used in the first phase of spermatogonial development during spermatogenesis (DE OLIVEIRA \& VICENTINI 1998). Conversely, we detected a positive relationship between the sperm bundles and fat body mass. This is likely due to the fact that both variables show peak development just before the breeding season and then decrease after the start of the breeding season. Sperm bundles then become spermatozoa when the fat body is no longer used as an energy source.

RASTOGI et al. (1978) demonstrated the influence of temperature on spermatogenesis in R. esculenta. In general, the proliferative activity of the first spermatogenic stages is low at low temperatures and high at high temperatures (RASTOGI et al. 1990). For R. esculenta, the percentage of primary spermatocytes was highest in the wet season (austral summer). Similarly, we found that $R$. arenarum exhibits a high percentage of initial spermatogenic stages (ISPG, IISPG) during the wet season.

Spermatogenesis in amphibians is described as an extended and complex process that begins with the proliferation and differentiation of stem cell spermatogonia, proceeds through meiosis, and terminates with spermiogenesis to produce a full supply of male gametes for the forthcoming breeding season (RASTOGI et al. 1988). BURGOS \& MANCINI (1948) demonstrated that spermatogenic activity throughout the year in the testes of $R$. arenarum is distinguished by three phases: a) initial stages, represented by primary and secondary spermatogonia, which predominate from October to January; b) intermediate stages in which primary spermatocytes, and spermatids are observed during the summer and fall, and c) final stages in the winter months, with sperm bundles reaching the highest level in September. We distinguished the three phases described by BURGOS \& MANCINI (1948), but with an earlier initiation of stage 1 for the population of $R$. arenarum at Pie de Palo: populations of Pie de Palo exhibited the initial stages from September to March. The increase in ambient air temperature in late August, associated with the Zonda winds, could account for our finding that phase 1 starts a month earlier (CARETTA et al. 2004). We observed intermediate stage spermatogenic activity in summer and autumn, but also found intermediate stage activity in the early spring (September). The final stages, characterized by a large percentage of sperm bundles, reached their highest level in the cold months.

Overall, our findings are consistent with a species demonstrating a continuous spermatogenic cycle: testicular volume does not vary throughout the year, as has also been observed for other populations of R. arenarum (QUIROGA \& SANABRIA 2012). As the sperm cycle of $R$. arenarum is continuous, the germinal epithelium never achieves a resting state (CEI 1949). Another bufonid, R. spinulosa (Wiegmann, 1834), also has a continuous cycle with large seasonal variation and minimal spermatogonial mitotic activity in winter (BUSTOS-OBREGON \& AlLIENDE 1973; BUSTOS-OBREGON et al. 1973). The geographic and evolutionary origin of $R$. arenarum is tropical (CEI 1980) with a recent invasion into temperate regions. 
It is possible that males have retained the acyclic reproductive activity in common with tropical species (QUIROGA \& SANABRIA 2012).

SHALAN et al. (2004) suggested that testosterone is a hormonal modulator of spermatogenic activity in desert anuran species. In addition, plasma testosterone levels vary markedly among different toad species, from as low as $1.2 \mathrm{ng} / \mathrm{ml}$ in Bufo asper (Smith, 1931) (EMERSON \& HESS 1996) to as high as $130 \mathrm{ng} / \mathrm{ml}$ in amplexing Scaphiopus couchii (Baird, 1854) (HARVEY et al. 1997). The testosterone levels of $R$. arenarum (present study) varied from 33.89 to $146.45 \mathrm{ng} / \mathrm{ml}$. Plasma testosterone concentrations were highest during the dry season months, when aestivation occurs in $R$. arenarum. These results differ from records of $R$. jimi (Stevaux, 2002) and $R$. granulosa (Spix, 1824), which inhabit the Caatingas desert, where the levels of testosterone and dihydrotestosterone in plasma were higher during the breeding season compared to the drought (MADELAIRE \& GOMEZ 2016). Our focal population of $R$. arenarum emerges from aestivation in late August, beginning with breeding, when males initiate vocal activity during daylight hours (QUIROGA \& SANABRIA 2012). Diurnal call behavior increases the call performance in August, as calling during the warmer part of the day is more efficient (SANABRIA \& QUIROGA 2011). However, testosterone levels decrease in $R$. arenarum when males emerge from aestivation (CANosa \& Ceballos 2002; Denari \& Ceballos 2005). Individuals of $R$. arenarum remain in caves or under rocks during the winter and they aestivate from May to August (SANABRIA et al. 2005). They do not form a cocoon when underground, and typically emerge to feed and breed in late August or early September (CEI 1980; GALLARDO 1987).

We found no relationship between testosterone levels and fat body mass associated with the gonads. This result was not consistent with findings for other frog species that show a positive relationship between testosterone and fat body mass (FITZPATRICK 1976). $R$. arenarum has fat bodies located in other parts of body such as the axillary and inguinal regions. It is possible that it utilizes these fat bodies as alternative reserves. Spermatogenesis in $R$. arenarum showed a high percentage of sperm bundles in the dry season months, concordant with high levels of testosterone. LAVILLA \& ROUGES (1992) point out that the species of the genus $R$. arenarum sperm can be present throughout the year. Furthermore, the low concentration of testosterone, in our study, was related to the percentage of primary spermatocytes. This relationship is consistent with studies carried out by RASTOGI (1976) in normal toads (not hypophysectomized) that were injected with testosterone, in which it was also observed that the transformation of secondary spermatogonia in primary spermatocytes was blocked.

Androgens are predominant in the testes of $R$. arenarum in the non-breeding season (CANOSA \& CEBALlos 2002). We also found plasma testosterone showed "dissociation" with reproductive activity, with high values of testosterone outside of the breeding season, similarly to the findings of CANOSA et al. (2003) and DENARI \& CEBALlos (2005). Dissociated reproductive tactics (elevated levels of reproductive steroids in periods outside the breeding season), are consistent with animals that live in places with rigorous climates and predictable but truncated breeding periods (CREWS \& MOORE 1986; KROHMER et al. 1987). The focal population of $R$. arenarum in the Monte desert that we observed reproduce opportunistically, in concordance with dissociated reproductive tactics. CREWS \& MOORE (1986) suggested that androgens do not mediate activation behavior in animals with opportunistic reproduction. However, this would not be the case in our study population, which inhabits locations with permanent water. It is more likely that reproduction in $R$. arenarum exhibits evolutionary constraints determining that breeding begins in early spring (SANABRIA et al. 2005). We agree with CANOSA \& Ceballos (2002), however, that it is possible that low levels of steroids produced during the breeding season of $R$. arenarum could exert an action on the central nervous system and thus induce breeeding. It is also possible that other androgens such as 5-dihydrotestosterone (DHT) and androstenedione (A) could act in combination to activate breeding because they are synthesized in the testis of anurans together with testosterone (RASTOGI et al. 1986). Therefore, it is important to examine the role of the other hormones that could be involved in sexual activity of toads. 
In summary, throughout the study year male $R$. arenarum did not show changes in their testicular volume, and testes contained spermatozoa in the seminiferous tubules at all sampled times (sperm cycle is continuous). The spermatogenesis in $R$. arenarum showed a high percentage of sperm bundles and spermatozoa in the dry season, corresponding with high levels of testosterone. Therefore, we believe that the males have an asynchronous strategy for reproduction. The reproductive cycle of $R$. arenarum allows this species to colonize and successfully reproduce in varied environments, from tropical regions to deserts.

\section{Acknowledgments}

We thank F. Hertel and J. Robertson for correcting the English draft of this manuscript. We acknowledge N. Carreño and A. Vincenti for their assistance in sample processing. We thank the Secretaria de Estado de Ambiente y Desarrollo Sustentable of San Juan Province, Argentina for permission to conduct our research (SEA y DS 1300-4736). This research was supported by a grant from the Specific program from Universidad Nacional de Cuyo (2011-2014), by M. Fornés, and partially supported by a post-graduate fellowship from CONICET awarded to E. Sanabria.

\section{References}

ARZABE C. (1999). Reproductive activity patterns of anurans in two different altitudinal sites within the Brazilian Caatinga. Revista Brasileira de Zoologia, 16: 851-864.

https://doi.org/10.1590/S0101-81751999000300022

Brown G.P., Kelehear C. \& Shine R. (2011). Effects of seasonal aridity on the ecology and behavior of invasive cane toads in the Australian wet-dry tropics. Functional Ecology, 25: 1339-1347. https://doi.org/10.1111/j.1365-2435.2011.01888.x

Burgos M.H. \& MANCINI R.E. (1948). Ciclo espermatogénico de Bufo arenarum Hensel. Revista de la Sociedad Argentina de Biología, 24: 322-336.

Bustos-Obregon E. \& Alliende C. (1973). Spermatogonial renewal in amphibian testis. I. Mitotic activity in the breeding season. Archives of Biology (Brussels), 84: 329-339.

Bustos-Obregon E., Alliende C \& SCRNiede P. (1973). Spermatogonial renewal in amphibian testis. II. Seasonal variations and effect of temperature. Archives of Biology (Liège), 84: 465-473.

CABrera A.L. (1976). Enciclopedia Argentina de Agricultura y Jardinería. Editorial ACME S.A.C.I, Buenos Aires.

Callard I.P., Callard G.V., Lance V., Bolaffi J.L. \& Rosset J.S. (1978). Testicular regulation in nonmammalian vertebrates. Biology of Reproduction, 18: 16-43.

https://doi.org/10.1095/biolreprod18.1.16

CANOSA L.F. \& CEBALlos N.R. (2002). Seasonal changes in testicular steroidogenesis in the toad Bufo arenarum H. General and Comparative Endocrinology, 125: 426-434.

https://doi.org/10.1006/gcen.2001.7768

Canosa L.F., Pozzi A.G., Rosemblit C. \& Ceballos N.R. (2003). Steroid production in toads. Journal of Steroid Biochemistry \& Molecular Biology, 85: 227-223.

https://doi.org/10.1016/S0960-0760(03)00234-6

CARVAlho J.E., NAVAS C.A. \& PeReiRA I.C. (2010). Energy and water in aestivating amphibians. In: Navas C.A. \& Carbalho J.E. (eds) Progress in Molecular and Subcellular Biology: 141-170. São Paulo, Brazil. https://doi.org/10.1007/978-3-642-02421-4_7

Caretta A., Ortega A. \& Ortíz Maldonado A. (2004). Probabilidades de daño por viento zonda en la floración de frutales, vid y olivos Mendoza, Argentina. Revista de la facultad de Ciencias Agrarias, 36: $49-58$. 
CEI J.M. (1949). Generalidades sobre el ciclo sexual y el predominio de la espermato-génesis anual continua en varios batracios de la región chaqueña. Acta Zoológica Lilloana, 75: 27-544.

CEI J.M. (1980). Amphibians of Argentina. Monographs 2. Monitore Zoologico Italiano (NS), Italy.

Chieffi G., Rastogi R.K., Milone M. \& Iela L. (1980). Amphibian reproduction: reproductive physiology in the male Rana esculenta L. Bolletino di Zoologia, 47: 63-70.

https://doi.org/10.1080/11250008009440321

CREWS D. \& MOORE M. (1986). Evolution of mechanisms controlling mating behavior. Science, 231: 121-125. https://doi.org/10.1126/science.3941893

CRUMP M.L. (2015). Anuran reproductive modes: evolving perspectives. Journal of Herpetology, 49: 1-16. https://doi.org/10.1670/14-097

De Assis V.R., NAVAs C.A., MendonCA M.T. \& GOMES F.R. (2012). Vocal and territorial behavior in the Smith frog (Hypsiboas faber): Relationships with plasma levels of corticosterone and testosterone. Comparative Biochemistry and Physiology Part A, 163: 265-271.

https://doi.org/10.1016/j.cbpa.2012.08.002

Delgado M.J., GutiÉRrez P. \& Alonso M. (1989). Seasonal cicles in testicular activity in the frog, Rana perezi. General and Comparative Endocrinology, 73: 1-11.

Denari D. \& CeBallos N.R. (2005). 11ß-Hydroxysteroid dehydrogenase in the testis of Bufo arenarum: Changes in its seasonal activity. General and Comparative Endocrinology, 143: 113-120. https://doi.org/10.1016/j.ygcen.2005.03.006

De Oliveira C. \& Vicentini C.A. (1998). Descricao anatomica dos testículos e corpos adiposos de Scinax fuscovarius (Anura, Hylidae). Biociências, 6: 79-98.

De Oliveira C., Sant’Anna A.C., Munhoz de Omena P., De SouZa Santos L.R. \& Zieri R. (2003). Morphological considerations on the seminiferous structures and testes of anuran amphibians: Bufo crucufer, Physalaemus cuvieri and Scinax fuscovarius. Biociências, 11: 39-46.

De Souza SAntos L.R. (2006). Ciclo reproductivo de machos de Dendropsophus minutus (Anura, Hylidae). PhD Thesis, Universidade Estadual Paulista. Sao Paulo, Brazil.

De Souza SAntos L.R. \& De Oliveira C. (2008). Histological aspects and structural characteristics of the testes of Dendropsophus minutus (Anura, Hylidae). Micron, 39: 1266-1270.

https://doi.org/10.1016/j.micron.2008.03.006

Duellman W.E. \& Trueb L. (1994). Biology of Amphibians. The Johns Hopkins University Press, Baltimore and London.

DUNHAM A.E. (1983). Realized niche overlap, resource abundance and intensity of interspecific competition. In: HUEY R.B., PIANKA E.R. \& SCHOENER T.W. (eds) Lizard Ecology. Harvard University Press, Cambridge, USA. https://doi.org/10.4159/harvard.9780674183384.c15

EMERSON S.B. \& HESS D.L. (1996). The role of androgens in opportunistic breeding, tropical frogs. General and Comparative Endocrinology, 103: 220-230. https://doi.org/10.1006/gcen.1996.0113

FERNÁNDEZ S.N. \& RAMOS I. (2003). Endocrinology of reproduction. In: JAMIESON B.G.M. (ed.) Reproductive Biology and Phylogeny of Anura: 73-117. Science Publishers, Enfield, London.

FITZPATRICK L.C. (1976). Life history patterns of storage and utilization of lipids for energy in amphibians. American Zoology, 16: 725-732. https://doi.org/10.1093/icb/16.4.725

Gallardo J.M; (1987). Anfibios de Argentina, Guía para su identificación. Biblioteca Mosaico. Argentina.

HAMMER Ø., HARPER D.A. \& RYAN P.D. (2001). PAST: Paleontological Statistics Software Package for Education and Data Analysis. Paleontología Electrónica, 4: 1-9. Available from

http://palaeo-electronica.org/2001_1/past/issue1_01.htm [accessed 16 April 2018]. 
Harvey L.A., Propper C.R., Woodley S. \& Moore M. (1997). Reproductive endocrinology of the explosively breeding desert spadefoot toad, Scaphiopus couchii. General and Comparative Endocrinology, 105: 102-113. https://doi.org/10.1006/gcen.1996.6805

HAU M. (2007). Regulation of male traits by testosterone: implications for the evolution of vertebrate life histories. Biossays, 29: 133-144. https://doi.org/10.1002/bies.20524

Heyer W.R., Donelly M.A., McDiarmid R.W., Hayek L.C. \& Foster M.S. (2001). Medición y monitoreo de la diversidad biológica, métodos estandarizados para anfibios. Editorial Universitaria de la Patagonia. Argentina.

HUANG W.S. \& YU J.Y. (2005). Reproductive characteristics of Bufo bankorensis at two elevations in Taiwan. Zoological Science, 22: 111-117. https://doi.org/10.2108/zsj.22.111

HUANG W.S., Lin J.Y. \& YU J.Y. (1997). Male reproductive cycle of the toad Bufo melanostictus in Taiwan. Zoological Science, 14: 497-503. https://doi.org/10.2108/zsj.14.497

ITOH M., INOUE M. \& ISHII S. (1990). Annual cycle of pituitary and plasma gonadotropins and sex steroids in a wild population of the toad, Bufo japonicus. General and Comparative Endocrinology, 78: 242-253. https://doi.org/10.1016/0016-6480(90)90011-A

JøRGENSEN C.B. (1992). Growth and reproduction. In: FEDER M.E. \& BURGGREN W.W. (eds) Environmental Physiology of the Amphibians: 439-466. The University of Chicago Press, USA.

Kordonowy L., Lombardo K.D., Green H.L., Dawson M.D., Bolton E.A., LaCourse S. \& MACMANeS M.D. (2017). Physiological and biochemical changes associated with acute experimental dehydration in the desert adapted mouse, Peromyscus eremicus. Physiological Reports, 5: e13218. https://doi.org/10.14814/phy2.13218

Krohmer R.W., Grassman M. \& CREWS D. (1987). Annual reproductive cycle in the male red-sided garter snake, Thamnophis sirtalis parietalis: field and laboratory studies. General and Comparative Endocrinology, 68: 64-75. https://doi.org/10.1016/0016-6480(87)90061-X

LAVILla E.O. \& Rouges M. (1992). Reproducción y desarrollo de anuros Argentinos. Asociación Herpetológica Argentina. Serie divulgación, 5: 1-66.

Licht P., McCreery B.R., BARNeS R. \& PANG R. (1983). Seasonal and stress related changes in plasma gonadotropins, sex stedoids, and corticosterone in the bullfrog, Rana catesbeiana. General and Comparative Endocrinology, 50: 124-145.

LONG D.R. (1987). A comparison of energy substrates and reproductive patterns of two anurans, Acris crepitans and Bufo woodhousei. Comparative Biochemistry and Physiology, Part A, 87: 81-91. https://doi.org/10.1016/0300-9629(87)90429-4

LONG D.R. (1989). Energetics and reproduction in female Scaphiopus multiplicatus from western Texas. Journal of Herpetology, 23: 176-179. https://doi.org/10.2307/1564026

MADELAIRE C.B. \& GOMES F.R. (2016). Breeding under unpredictable conditions: annual variation in gonadal maturation, energetic reserves and plasma levels of androgens and corticosterone in anurans from the Brazilian semi-arid. General and Comparative Endocrinology, 228: 9-16.

https://doi.org/10.1016/j.ygcen.2016.01.011

MAdelaire C.B., SoKolova I. \& GoMes F.R. (2017). Seasonal patterns of variation in steroid plasma levels and immune parameters in anurans from Brazilian semiarid area. Physiological and Biochemical Zoology, 90: 415-433. https://doi.org/10.1086/691202

Medina M.F., Ramos I., Crespo C.A., GonZÁlez-CAlvar S. \& FernÁndez S.N. (2004). Changes in serum sex steroid levels throughout the reproductive cycle of Bufo arenarum females. General and Comparative Endocrinology, 136: 143-151. https://doi.org/10.1016/j.ygcen.2003.11.013 
MENDONÇA M.T., Licht P., RYAN M.J. \& BARNes R. (1985). Changes in hormone levels in relation to breeding behavior in male bullfrogs (Rana catesbeiana) at the individual and population levels. General and Comparative Endocrinology, 58: 270-279.

MONTERO R. \& PISANÓ A. (1990). Spermatogenic cycle of two species of Telmatobius the Argentine northeast. Amphibia-Reptilia, 11: 97-110.

MONTERO R. \& PisANÓ A. (1992). El ciclo espermatogénico anual de Hyla pulchella andina: un análisis numérico. Acta Zoológica Lilloana, 41: 173-180.

NAVAS C.A., Gomes F.R. \& CARVALho J.E. (2008). Thermal relationship and exercise physiology in anuran amphibians: integration and evolutionary implications. Comparative Biochemistry \& Physiology Part A, 151: 344-362. https://doi.org/10.1016/j.cbpa.2007.07.003

Perotti M.G. (1997). Modos reproductivos y variables reproductivas cuantitativas en un ensamble de anuros del chaco semiárido, Salta, Argentina. Revista Chilena de Historia Natural, 70: 277-288.

QUIROGA L.B. \& SANABRIA E.A. (2012). Variation in reproductive parameters of Rhinella arenarum (Hensel, 1867) (Anura: Bufonidae) between the reproductive and post-reproductive periods. Belgian Journal of Zoology, 142: 68-73.

Quiroga L., SANABria E. \& ACosta J. (2009). Size- and sex-dependent variation in diet of Rhinella arenarum (Anura: Bufonidae) in a wetland of San Juan, Argentina. Journal of Herpetology, 43: 311317. https://doi.org/10.1670/07-117R2.1

RASBAND W. (2008). Image J, version 1.41. National Institutes of Health, Bethesda, Maryland. U.S. http://imagej.nih.gov/ij/

RASTOGI R.K. (1976). Seasonal cycle in anuran (Amphibia) testis: The endocrine and environmental controls. Bolletino di Zoologia, 43: 151-172. https://doi.org/10.1080/11250007609434893

Rastogi R.K., IEla L., SAXena P.K. \& ChiefFi G. (1976). The control of espermatogenesis in the green frog Rana esculenta. Journal of Experimental Zoology, 196: 151-166.

Rastogi R.K., Iela L., Delrio G., Di Meglio M., Russo A. \& Chieffi G. (1978). Environmental influence on testicular activity in the green frog, Rana esculenta. Journal of Experimental Zoology, 206: 49-64. https://doi.org/10.1002/jez.1402060106

Rastogi R.K., Iela L., Delrio G. \& Bagnara J.T. (1986). Reproduction in the Mexican leaf frog, Pachymedusa dacnicolor. II The male. General and Comparative Endocrinology, 62: 23-35. https://doi.org/10.1016/0016-6480(86)90090-0

Rastogi R.K., Bagnara J.T., IEla L. \& Krasovich M.A. (1988). Reproduction in the Mexican leaf frog, Pachymedusa dacnicolor. IV. Spermatogenesis: a light and ultrasonic study. Journal of Morphology, 197: 277-302. https://doi.org/10.1002/jmor.1051970304

Rastogi R.K., Di Mateo L., MinuCci S., Di Meglio M. \& Iela L. (1990). Regulation of primary spermatogonial proliferation in the frog (Rana esculenta): an experimental analysis. Journal of Zoology, 220: 201-211. https://doi.org/10.1111/j.1469-7998.1990.tb04303.x

SANABRIA E.A. \& QUIROGA L.B. (2011). Thermal parameters changes in males of Rhinella arenarum (Anura: Bufonidae) related to reproductive periods. Revista de Biología tropical, 59: 347-353.

SANABRIA E.A., Quiroga L.B. \& ACOSTA J.C. (2005). Patrones de actividad temporal estacional y uso de microhábitat de una población de adultos de Bufo arenarum, en los humedales de Zonda, San Juan, Argentina. Boletín de la Sociedad Herpetológica Mexicana, 13: 61-65.

SASSO-Cerri E., De FARIA F.P., Freymüller E. \& Miraglia S.M. (2004). Testicular morphological changes the seasonal reproductive cycle in the Bullfrog Rana catesbeiana. Journal of Experimental Zoology Part A, 301: 249-260. https://doi.org/10.1002/jez.a.20023 
SEYMOUR R.S. (1973). Energy metabolism of dormant spadefoot toads (Scaphiopus). Copeia, 1973: 435-445. https://doi.org/10.2307/1443107

Shalan A.G., BradshaW S.D., Withers P.C., THOMPSON G., BAYOMY M.F.F., BrADSHAW F.J. \& STEWART T. (2004). Spermatogenesis and plasma testosterone levels in western Australian burrowing desert frogs, Cyclorana platycephala, Cyclorana maini, and Neobatrachus sutor, during aestivation. General and Comparative Endocrinology, 136: 90-100. https://doi.org/10.1016/j.ygcen.2003.12.005

SPECKER J.L. \& MOORE F.L. (1980). Annual cycle of plasma androgens and testicular composition in the rough-skinned newt, Taricha granulosa. General and Comparative Endocrinology, 42: 297-303. https://doi.org/10.1016/0016-6480(80)90158-6

StebBins R.C. \& COHEN N.W. (1997). A Natural History of Amphibians. Princeton University Press, USA.

Tieleman B.I., Williams J.B. \& Buschur M.E. (2002). Physiological adjustments to arid and mesic environments in larks (Alaudidae). Physiological and Biochemical Zoology, 75: 305-313.

https://doi.org/10.1086/341998

TSIORA A. \& KYRIAKOPOULOU-SKLAVOUNOU P. (2001). Male reproductive cycle of the water frog Rana epeirotica in northwestern Greece. Amphibia-Reptilia 22: 291-302.

https://doi.org/10.1163/156853801317050089

Wells D.W. (2007). The Ecology and Behavior of Amphibians. The Universiy of Chicago Press, Chicago, USA. https://doi.org/10.7208/chicago/9780226893334.001.0001

Whitford W.G. (2002). Ecology of Desert Systems. Academic Press, New Mexico State University, Las Cruces, USA.

Woolbright L.L. (1989). Sexual dimorphism in Eleutherodactylus coqui: selection pressures and growth rates. Herpetologica, 45: 68-74.

Manuscript received: 19 June 2017

Manuscript accepted: 19 January 2018

Published on: 30 May 2018

Branch editor: Roger Huybrechts 